\title{
Foamy gland variant of adenocarcinoma of prostate: a rare pathological variant
}

\author{
Aditi Arora, Ritika Jaiswal, Nidhi Anand, Nuzhat Husain
}

Department of Pathology, Dr Ram Manohar Lohia Institute of Medical Sciences, Lucknow, Uttar Pradesh, India

Correspondence to Dr Aditi Arora,draditiarora87@gmail. com

Accepted 21 December 2016

CrossMark

To cite: Arora $A$, Jaiswal $R$, Anand N, et al. BMJ Case Rep Published online: [please include Day Month Year] doi:10.1136/bcr-2016218384

\section{DESCRIPTION}

A 58-year-old man presented with history of irritative lower urinary tract symptoms (daytime frequency and nocturia) for 3 months. Digital rectal examination revealed grade 2 prostatomegaly and consistency was hard. Serum prostate-specific antigen (PSA) was $2.7 \mathrm{ng} / \mathrm{mL}$. Serum creatinine was $1.2 \mathrm{mg} / \mathrm{dL}$. Transrectal ultrasonography (TRUS) revealed a prostate size of $54 \times 47 \times 56 \mathrm{~mm}$ with hypoechoic nodular appearance at superior part of the left lobe. Ultrasound scan of the abdomen was normal. Urinary microscopy revealed $1-2$ pus cells and 3-4 erythrocytes. TRUS-guided 12-core biopsy was performed. Microscopic examination of all the biopsy cores revealed fused glandular structures with focal cribriform pattern (Gleason pattern 4 $+4=8$ ), involving $>80 \%$ of the prostatic cores (figures 1 and 2). Perineural invasion was evident. Individual cells were polygonal with voluminous foamy cytoplasm, low nucleo-cytoplasmic ratio, pyknotic nuclei and inconspicuous nucleoli. Tumour cells were immunoreactive for PSA while p63 and 34ßE12 confirmed the absence of basal cell layer (figure 3 ). Radical prostatectomy was performed. PSA nadir $(0.01 \mathrm{ng} / \mathrm{mL})$ was achieved at 1 month post procedure. The patient is doing well after 12 months of follow-up with no evidence of recurrent or residual disease.

Foamy gland variant of prostatic adenocarcinoma was first described in 1996 by Nelson and Epstein. ${ }^{1}$ It occurs in a significant proportion (17\%) of cases of carcinoma prostate diagnosed on needle biopsy. ${ }^{2}$ Age at presentation ranges from 50 to 78 years. The tumour cells are deceptively benign and characteristically have abundant foamy cytoplasm, bland pyknotic nuclei and inconspicuous nucleoli.

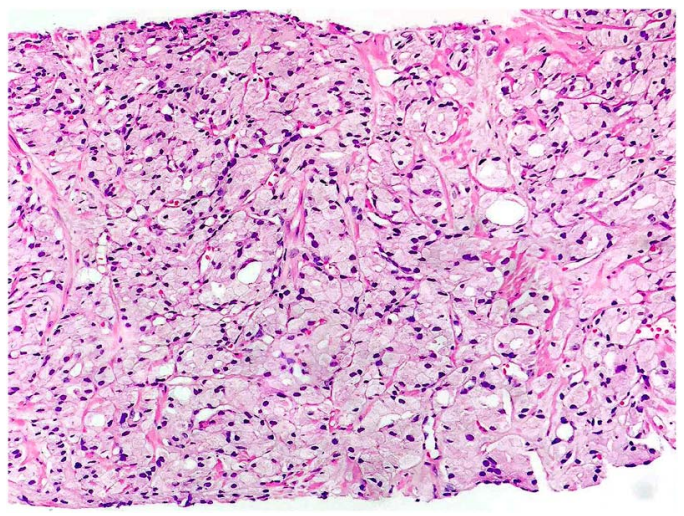

Figure 1 Needle core biopsy showing diffuse infiltration by a tumour composed of crowded glands lined by cells showing voluminous foamy cytoplasm. The overall Gleason score was $4+4=8$.

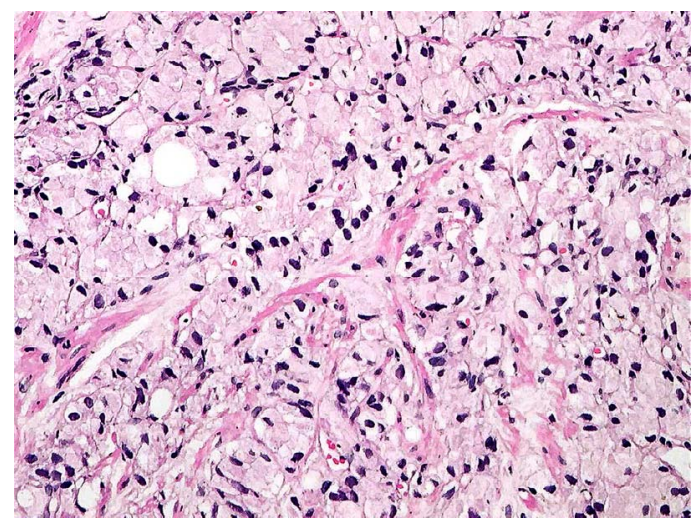

Figure 2 Foamy gland carcinoma showing fused glandular structures with cells having abundant foamy cytoplasm, small pyknotic bland looking nuclei and absent nucleoli.
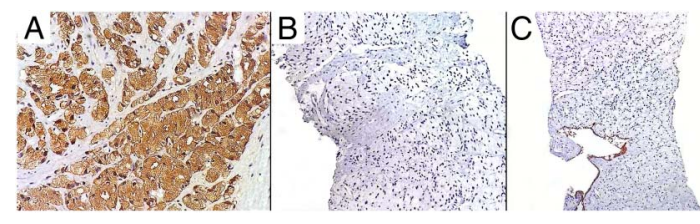

Figure 3 Immunohistochemical stains. (A) Tumour cells staining positive with PSA. (B) p63 demonstrates the absence of basal cell layer in the tumour. (C) $34 \beta E 12$ shows the absence of basal cell layer in the tumour.

International Society of Urologic Pathology (ISUP) recommends grading of these carcinomas based on the underlying architectural pattern. ${ }^{3}$ Prognosis depends on the Gleason score and the presence or absence of perineural or extra prostatic extension. Recognition of this variant poses a challenge for an uropathologist and can be missed on needle biopsy.

\section{Learning points}

Foamy gland variant of prostatic adenocarcinoma mimics benign glands.

- It is important for the pathologist to be aware of this entity as foamy gland carcinoma in pure form can be easily missed on needle biopsy.

- Gleason scoring of this variant is performed by the underlying architectural pattern.

Contributors AA involved in planning, conduct, reporting, conception and design, acquisition of data or analysis. RJ is 
responsible for conduct, reporting, conception and design, interpretation of data. NA reviewed the literature and involved in writing the manuscript. NH is responsible for supervision, review of the literature and analysis of data.

Competing interests None declared.

Patient consent Obtained.

Provenance and peer review Not commissioned; externally peer reviewed.

\section{REFERENCES}

1 Nelson RS, Epstein Jl. Prostatic carcinoma with abundant xanthomatous cytoplasm: foamy gland carcinoma. Am J Surg Pathol 1996;20:419-26.

2 Warrick Jl, Humphrey PA. Foamy gland carcinoma of the prostate in needle biopsy. Incidence, Gleason grade, and comparative a-methylacyl-CoA racemase vs. ERG expression. Am I Surg Pathol 2013;37:1709-14.

3 Li J, Wang Z. The pathology of unusual subtypes of prostate cancer. Chin I Cancer Res 2016;28:130-43.

Copyright 2017 BMJ Publishing Group. All rights reserved. For permission to reuse any of this content visit http://group.bmj.com/group/rights-licensing/permissions.

BMJ Case Report Fellows may re-use this article for personal use and teaching without any further permission.

Become a Fellow of BMJ Case Reports today and you can:

- Submit as many cases as you like

- Enjoy fast sympathetic peer review and rapid publication of accepted articles

- Access all the published articles

- Re-use any of the published material for personal use and teaching without further permission

For information on Institutional Fellowships contact consortiasales@bmjgroup.com

Visit casereports.bmj.com for more articles like this and to become a Fellow 